\title{
28 Research Soure \\ Genetic variants of TLR9 Gene and Chronic Kidney Disease Susceptibility
}

Jin Ho Kwak

Soksiwon Kwak \& Lee Clinic

Gyeong Im Yu

Keimyung University School of Medicine

Woo Yeong Park

Keimyung University Dongsan Hospital: Keimyung University Dongsan Medical Center

Jin Hyuk Paek

Keimyung University Dongsan Hospital: Keimyung University Dongsan Medical Center

\section{Yaerim Kim}

Keimyung University Dongsan Hospital: Keimyung University Dongsan Medical Center

Dong Hoon Shin

Keimyung University School of Medicine

Kyubok Jin ( $\triangle$ mdjin922@gmail.com )

Keimyung University Dongsan Medical Center https://orcid.org/0000-0002-7836-8863

\section{Research article}

Keywords: Chronic kidney disease, IFNL, TLR9, Polymorphisms, Replication

Posted Date: February 9th, 2021

DOI: https://doi.org/10.21203/rs.3.rs-187772/v1

License: (c) (i) This work is licensed under a Creative Commons Attribution 4.0 International License. Read Full License 


\section{Abstract}

Objectives Chronic kidney disease (CKD) is a common condition that can lead to renal dysfunction and is closely in relation to an increased cardiovascular risk and mortality risk. CKD is an important public health issue, and recent genetic studies have verified common CKD susceptibility variants. In this research, we examined the interrelationship between candidate genes polymorphisms of IFNL induction and signaling pathway and CKD.

Methods 92 CKD patients and 330 healthy subjects as control were participated in this research. Replication set consisting 137 CKD with CGN patients and 446 controls was used for additional analysis. The genotype of SNPs was determined by the Axiom Genome-Wide Human Assay and SNaPshot assay.

Results The SNPs of IFNL3 and IFNL2 were significantly associated with chronic kidney disease in the codominant ( $p=0.015, p=0.013$, respectively). The SNP of IFNRA2 was significantly associated with chronic kidney disease in the codominant $(\mathrm{p}=0.029)$. The SNP of $T L R 9$ was significantly associated with chronic kidney disease in the codominant $(p=0.016)$, dominant $(p=0.047)$ and recessive $(p=0.049)$. The SNP of $I L-22$ was significantly associated with chronic kidney disease in the codominant $(p=0.049)$. No significant associations involving IFNL3, IFNL2 and IL22 were observed in the replication set whereas concerning the rs187084, in the $T L R 9$ gene, a significant association was observed pooling the original and the replication sets.

Conclusions This results shows a possibility that IFNL induction and signal pathway genes polymorphisms as a risk factor for CKD. Secondly, our results seem to TRL9 gene variant may be play a risk factor on CKD with CGN.

\section{Introduction}

The prevalence of Chronic kidney disease (CKD) in the world's population is 11-13\% [1, 2], which is closely related with a risk of hospitalizations and even death $[3,4]$. In fact, CKD is an economic issue for global healthcare as well as a medical issue [5]. Diabetes and hypertension are known as the most common major risk factors for CKD among other factors such as metabolic syndrome, low high-density lipoprotein cholesterol (HDL) and advanced age [6].

A significant association between a large number of genes and its polymorphisms and CKD development as well as function of kidney was found in numerous genetic researches. It can be concluded that a strong genetic component exists in CKD $[7,8]$. According to Lu and his colleagues, a relationship between CKD and the T-1237 polymorphism of the Toll-like receptor-9 (TLR-9) gene showed significance among Han Chinese population [9]. Also, the variation of the Transcription factor 7-like 2 gene and cardiovascular problems in advanced kidney disease patients showed a strong correlation presented by Buraczynska et al. [10]. Multiple loci related to CKD and eGFR were determined in East Asian and European populations by using Genome-Wide Association Studies (GWAS) [11, 12]. Gorski et al. [13] proposed that loci polypeptide N-acetylgalactosaminyltransferase 11 and cadherin related 23 has a role in kidney failure, and indicated a significant link between uromodulin locus and kidney failure in GWAS meta-analysis which was targeted 63,558 European-born participants. The relationship between the variation of renin-angiotensin-aldosterone system (RAAS) and progression of CKD was analysed by Kelly et al [14]. They confirmed that the RAAS variants are strongly pathway-and gene-based related with the progression of CKD. The risk of kidney events in chronic kidney disease cohort study showed consistent relationship with the angiotensinogen and renin binding protein genes [14]. 
Also known as type III Interferon (type III IFN) or interleukin (IL)-28 and IL-29, interferon lambda (IFNL) is affiliated to a cytokine family that has several similarities in functions with type I IFNs family (IFN- $\alpha$ and/or IFN- $\beta$, IFN- $\alpha / \beta$ ). The four IFNL proteins (IFNL1, IFNL2, IFNL3, and IFNL4) and 17 IFN- $\alpha / \beta$ proteins [13] IFN- $\alpha$ subtypes, IFN- $\beta$, IFN- $\omega$, IFN- $\varepsilon$, and IFN-K) are encoded by genes inside human [15]. Located in human chromosome 19, genes encoding IFNL has similar gene structure with the 5-exon gene of IL-10 cytokine family [16].

IFNL has several biologic features, which starts with the effectiveness of IFNL. The efficacy of IFNL is most pronounced in epithelial cells, specifically speaking, it strengthens the immune systems that protect the surface of the upper skin where exposed to general and pathogenic microorganisms at all times. Second, considering the nature of IFNL signaling effect, there is a possibility that IFNL has similar effect in therapeutic aspect as in IFN-a/ $\beta$. Third, researches in genome-wide association identified the interrelationship between several IFNL polymorphisms and removal of hepatitic $C$ virus infection, furthermore, the possibility to improve other viral infections such as hepatitis B virus and herpes simplex virus 1 [17-19]. The immunologic roles of IFNL, however,

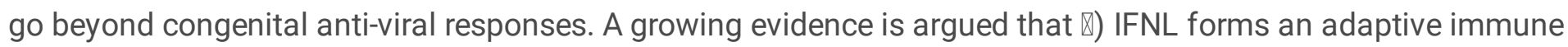
response to virus infection, $\nabla$ ) changes anti-tumor responses, and $\nabla$ ) affects autoimmune properties such as autoimmune arthritis and allergic asthma [20].

After Host detection of pathogenic-related molecular patterns by certain pattern recognition receptors (PRRs), IFN representation takes place. Transcription factors activated downstream of PRR signaling include interferon regulatory factors (IRFs) and nuclear factor kappa B subunit (NF-K $\beta$ ). Early characteristic distinguishing of promoter areas at upstream of interferon lambda 1 (IFNL1) and IFNL3 verified combine elements for IRF-1, IRF-3, IRF-7, and NF-K $\beta$. Also, for maximum gene induction, combining IRFs and NF-K $\beta$ was requested. IFNL (type III IFNs) combines to a unique heterodimeric receptor, interferon lambda receptor (IFNLR). IFNLR is comprised of a subunit shared with another IL-10 family cytokine and a seconds for IFN- $\lambda$ [21-24].

Toll-like receptors (TLRs) was verified as a major element of pathological recognition process in the human inflammatory responses to infectious diseases. TLR3 and TLR7 for viruses, TLR9 for bacteria are displayed by plasmacytoid dendritic cells. Microorganisms activating the immune mechanism by Toll-like receptor ligation can cause or deteriorate glomerular disease. Hyper-activation of TLRs is related to the acute rejection of renal transplantation, acute infection of tubulointerstitium in kidney, acute kidney injury and ischemic kidney damage $[25,26]$.

Since an anti-inflammatory cytokine secreted by various cell types, IL-10, these immune suppression effects involve inhibiting the proliferation of T cells, inhibiting the production of co-stimulatory protein expression on antigen-presenting cells, and restricting the production of pro-inflammatory cytokine. IL-10 receptor (IL-10R), composed of two a subunits, encoded by interleukin 10 receptor subunit alpha (IL-10RA) and two $\beta$ subunits, encoded by interleukin 10 receptor subunit beta (IL-10RB), activates Janus kinase 1 (JAK1) and tyrosine kinase 2 (TYK2) resulting in phosphorylation and nuclear translocation of signal transducer and activator of transcription 3 (STAT3) and gene transcription. IL-10RB is situated in a class II cytokine receptor gene cluster along with interferon alpha receptor 1 (IFNAR1), interferon alpha receptor 2 (IFNAR2), and interferon gamma receptor 2 (IFNGR2) on chromosome 21q22 [27].

This research examined the association between IFNL induction and signaling pathway candidate genes such as IFNL3, IFNL2, IFNAR2, TLR9, IL-22, IL-10RB, interferon receptor alpha (IFNRA), IRF7, JAK2, and STAT3 polymorphisms and CKD. 


\section{Materials And Methods \\ Study Subjects}

A total of 92 CKD patients distributed by the Keimyung Human Bio-Resource Bank in 2012 and 330 control subjects with no clinical evidence for cancer, hypertension, diabetes mellitus, dyslipidemia, Cardiovascular diseases, who had took health check-up program in health promotion center, from July to October 2008. Replication set consisting 137 CKD with CGN patients and 446 controls was used for additional analysis. 137 CKD with CGN patients samples were consecutively distributed by the Keimyung Human Bio-Resource Bank in 2018 and controls were collected at the health promotion center of Keimyung University Dongsan Medical Center.

Written informed consent was provided to all subjects. Institutional review of board, Keimyung University Dongsan Medical Center approved protocol was used for this study (IRB No. 2018-02-029).

\section{Clinical characteristics and Biomedical Measurement}

Clinical characteristics such as systolic blood pressure (SBP), diastolic blood pressure (DBP) of participants were measured. The body mass index (BMI) is calculated by weight divided by square of the height $\left(\mathrm{kg} / \mathrm{m}^{2}\right)$.

Biochemical markers were measured using samples in the fasted state. The levels of fasting blood sugar (FBS), triglyceride (TG), total cholesterol (TC), low density lipoprotein (LDL) cholesterol, high density lipoprotein (HDL) cholesterol, aspartate aminotransferase (AST), alanine aminotransferase (ALT), albumin, blood urea nitrogen (BUN), creatinine, and uric acid were measured by auto analyzer (ADVIA ${ }^{\circledR} 2400$ Chemistry System, Siemens Healthcare Diagnostics Inc., Tarrytown, NY, USA). The estimated glomerular filtration rate (eGFR) was calculated with the use of the simplified prediction equation derived from the chronic kidney epidemiology collaboration (Modification of Diet in Renal Disease) : estimated GFR $=175 \times$ standardized Scr $^{-1.154} \times$ age $^{-0.203} \times 0.742$ [if female], where GFR is expressed as $\mathrm{mL} / \mathrm{min} / 1.73 \mathrm{~m} 2$ of body surface area and Scr is expressed in $\mathrm{mg} / \mathrm{dl}$ [28].

\section{SNPs selection and genotyping of the Interferon Lambda- Related gene SNPS}

17 SNPs in the (IFNL3 gene 2SNPs, IFNL2 gene 2SNPs, IFNAR2 gene 2SNPs, TLR9 gene 2SNPs, IL-22 gene 2SNPs, IL 10-RB gene 2SNPS, IFNARA gene 1SNP, IRF7 gene 1SNP, JAK2 gene 1SNP and STAT3 gene 1SNP) of interferon lambda-related gene were selected based on database searches (http://ncbi.nlm.nih.gov/SNP). SNPs with $<0.05$ minor allele frequency (MAF), $<0.1$ heterozygosity and unknown genotype frequencies in Asian populations were excluded. Human genomic DNA was extracted from peripheral blood samples using the Qiagen DNA extraction Kit (Qiagen, Tokyo, Japan) and then stored at $20^{\circ} \mathrm{C}$. The SNPs of IFNL3, IFNL2, IFNAR2, TLR9, IL22, IL-10RB, IFNRA, IRF7, JAK2, and STAT3 genes were genotyped by direct sequencing, respectively. The following primers for the seventeen SNPs were used to amplifier genomic DNA (Table 1). Polymerase chain reaction (PCR) conditions included 32 cycles at $92{ }^{\circ} \mathrm{C}$ for $30 \mathrm{sec}, 60{ }^{\circ} \mathrm{C}$ for $50 \mathrm{sec}$, and $70{ }^{\circ} \mathrm{C}$ for $40 \mathrm{sec}$. PCR products were identified on $1.5 \%$ agarose gel by electrophoresis. To analyze the genotypes of each SNP, PCR products were sequenced by the DNA analyzer (ABI Prism 3730XL, Applied Biosystems, Foster City, CA, USA) and the genotypes were determined using SeqManll software (DNASTAR Inc., Madison, WI, USA). 
Table 1

PCR Primers of Single Nucleotide Polymorphisms in the Interferon Lambda-Related genes

\begin{tabular}{|c|c|c|c|c|}
\hline Gene & SNP & Forward & Reverse & $\begin{array}{l}\text { Product } \\
\text { Size }\end{array}$ \\
\hline IFNL3 & rs148543092 & 5'-GAGGATATGGTGCAGGGTGT-3' & $\begin{array}{l}\text { 5'-СТСТАТССТССТСССССААС- } \\
3^{\prime}\end{array}$ & $201 \mathrm{bp}$ \\
\hline IFNL3 & rs150748693 & 5'-GAAGGGTCAGACACACAGGT-3' & $\begin{array}{l}\text { 5'-GAGCCCAGAACCCAGACAG- } \\
3^{\prime}\end{array}$ & $152 \mathrm{bp}$ \\
\hline IFNL2 & rs8103362 & 5'-СССТСАССTGCTCTTTCTCA-3' & $\begin{array}{l}\text { 5'-GAGGATATGGTGCAGGGTGT- } \\
3^{\prime}\end{array}$ & $163 \mathrm{bp}$ \\
\hline IFNL2 & rs59746524 & 5'-CCCACAGATCCAGCCTCAG-3' & $\begin{array}{l}\text { 5'-TGTAGGGAGGAGGGGATGG- } \\
3^{\prime}\end{array}$ & 183 bp \\
\hline IFNAR2 & rs2229207 & 5'-CAAAGATGCTTTTGAGCCAGA-3' & $\begin{array}{l}5^{\prime}- \\
\text { TTGCTTTCCACTTAACTCCTGA- } \\
3^{\prime}\end{array}$ & 208 bp \\
\hline IFNAR2 & rs1051393 & $\begin{array}{l}5^{\prime}- \\
\text { TTGATCACCTAATGTTGATTTCAGA- } \\
3^{\prime}\end{array}$ & $\begin{array}{l}\text { 5'-AGGGTGGTACTGGGTCCTCT- } \\
3^{\prime}\end{array}$ & 234 bp \\
\hline$T L R 9$ & rs187084 & 5'-GCTGGGTGTACATAATTCAGCA-3' & $\begin{array}{l}\text { 5'-GAGCTCCTTTGCCTGGTCTA- } \\
3^{\prime}\end{array}$ & 220 bp \\
\hline$T L R 9$ & rs5743836 & 5'-GGGGTGGGAGGTTTGTAAGA-3' & 5'-CTGTTCСССTGAGTGСTCT-3' & 217 bp \\
\hline IL-22 & rs2227513 & 5'-СТTСТАССТTССССGTCACA-3' & $\begin{array}{l}\text { 5'-GGTCCCCATAAGGAAAGAGC- } \\
3^{\prime}\end{array}$ & $218 \mathrm{bp}$ \\
\hline IL-22 & rs2227484 & $\begin{array}{l}\text { 5'- } \\
\text { GATATATTTACTTCTGCCTTAATTG- } \\
3^{\prime}\end{array}$ & $\begin{array}{l}\text { 5'- } \\
\text { GGACCCATGTCCTATATCCTC-3' }\end{array}$ & 220 bp \\
\hline IL-22 & rs2227485 & 5'-TCCGTGACCAAAATGCTTACTC-3' & $\begin{array}{l}\text { 5'-ACGTCACTATTAGAGCCCGG- } \\
3^{\prime}\end{array}$ & $165 \mathrm{bp}$ \\
\hline $\begin{array}{l}\text { IL- } \\
\text { IORB }\end{array}$ & rs8178562 & 5'-TCAGAAGTTGGCCACTGAGA-3' & $\begin{array}{l}\text { 5'-CGCCATCATGCCTAGCTAAT- } \\
3^{\prime}\end{array}$ & $231 \mathrm{bp}$ \\
\hline $\begin{array}{l}\text { IL- } \\
10 R B\end{array}$ & rs2834167 & $\begin{array}{l}5^{\prime}- \\
\text { CTCTCTACCTCTTCCGCCGTCTACA- } \\
3^{\prime}\end{array}$ & $\begin{array}{l}\text { 5'-GGTCCCCATAAGGAAAGAGC- } \\
3^{\prime}\end{array}$ & $223 \mathrm{bp}$ \\
\hline IFNRA & $\begin{array}{l}\text { Affx- } \\
52347487\end{array}$ & 5'-GAGAAACTGGGGGTCCCCCA-3' & 5'-GCTCCGGTGGTAAGGTGC-3' & 104 bp \\
\hline IRF7 & $\begin{array}{l}\text { Affx- } \\
52325648\end{array}$ & 5'-GCTACACGGAGGAACTGCTG-3' & $\begin{array}{l}\text { 5'-GCCTCACTGACCTTGGAAGA- } \\
3^{\prime}\end{array}$ & 218 bp \\
\hline$J A K 2$ & rs77375493 & 5'-AGCAAGTATGATGAGCAAGCT-3' & $\begin{array}{l}5^{\prime}- \\
\text { ACCTAGCTGTGATCCTGAAACT- } \\
3^{\prime}\end{array}$ & $163 \mathrm{bp}$ \\
\hline STAT3 & rs113994139 & 5'-TTССТTСССАТGTССТGTGA-3' & $\begin{array}{l}\text { 5'-CTGGCCGACAATACTTTCCG- } \\
3^{\prime}\end{array}$ & 203 bp \\
\hline
\end{tabular}


Genotyping of replication SNP was screened using single base primer extension assay using ABI PRISM SNaPShot Multiplex kit (ABI, Foster City, CA, USA) according to manufacturer's recommendation. Analysis was carried out using Genemapper software (version 4.0; Applied Biosystems)

\section{Statistical Analysis}

The window version 24.0 of statistical package for SPSS (SPSS Inc., Chicago, IL, USA) and R version 3.2.2 were used for statistical analysis. The results were considered statistically significant when $p<0.05$. Continuous variable comparison between the two groups were used for Student's t-test. Continuous variable were presented as mean \pm standard deviation. Categorical variable comparison between the two groups were used for chi-square $(\chi 2)$ test and were presented as frequency and percentage and odds ratio (OR) and 95\% confidence interval (Cl) were calculated. For the estimation of Hardy-Weinberg equilibrium (HWE) and analysis of logistic regression for the genetic data were used for SNPStats (http://bioinfo.iconcologia. net/index.php) and SPSS 24.0. The Allele frequencies comparison between the two groups were used for chi-square $(\chi 2)$ test. The associations between SNPs and CKD were estimated by computing the OR and their $95 \% \mathrm{Cl}$ with logistic regression analyses, adjusted for age and gender as covariates. In the CKD patients group, Multivariate logistic regression analysis of gene data and clinical variables was used with R version 3.2.2. age, gender, BMI, hypertension, diabetes mellitus, and dyslipidemia were adjusted as covariates in multivariate logistic regression.

\section{Result}

\section{Demographic and clinical characteristics of participants}

The demographic characteristics and clinical parameters of the study subjects are summarized in Table 2 . Three hundred and thirty control subjects included 165 male and 165 female with a mean age of $47.0 \pm 13.3$ years. The CKD group was composed of 92 adults and included 44 male and 48 female with a mean age of $49.9 \pm$ 11.9 years. The distribution of gender of the subjects was not significantly different in the two groups. The levels of BMI, SBP, DBP, BUN, creatinine, uric acid, FBS, and TG in the CKD group were significantly higher than those of the control group $(p<0.05)$. The levels of eGFR, total protein, albumin, total cholesterol, HDL cholesterol, and LDL cholesterol in the CKD group were significantly lower than those of the control group $(p<0.05)$. Estimated glomerular filtration rate (eGFR) < 60 was found 18 controls $(5.5 \%)$ and 90 CKD patients $(97.8 \%)$. In the control and CKD group, the genotype distribution of the seventeen polymorphic SNPs were in the Hardy-Weinberg equilibrium (HWE) $(p>0.05)$. 
Table 2

Demographic characteristics and clinical parameters for the study population

\begin{tabular}{|c|c|c|c|}
\hline & \multirow{2}{*}{$\begin{array}{l}\text { Control } \\
(\mathrm{N}=330)\end{array}$} & \multirow{2}{*}{$\begin{array}{l}\text { CKD } \\
(N=92)\end{array}$} & \multirow[t]{2}{*}{ p-value } \\
\hline & & & \\
\hline Age (years) & $47.0 \pm 13.3$ & $49.9 \pm 11.9$ & 0.02 \\
\hline Male & $47.3 \pm 10.5$ & $51.8 \pm 9.5$ & \\
\hline Female & $46.7 \pm 10.1$ & $48.2 \pm 13.5$ & \\
\hline \multicolumn{4}{|l|}{ Gender } \\
\hline Male / Female n (\%) & $165(50.0) / 165(50.0)$ & $44(47.8)$ / 48 (52.2) & 0.725 \\
\hline \multicolumn{4}{|l|}{ Etiology } \\
\hline Diabetes Mellitus n (\%) & & $28(30.4)$ & \\
\hline Hypertension n (\%) & & $4(4.3)$ & \\
\hline CGN n (\%) & & $58(63.0)$ & \\
\hline Others n (\%) & & $2(2.2)$ & \\
\hline LVH n (\%) & & $18(19.6)$ & \\
\hline Body Mass Index $\left(\mathrm{kg} / \mathrm{m}^{2}\right)$ & $22.5 \pm 2.6$ & $23.8 \pm 3.6$ & 0.002 \\
\hline Systolic Blood Pressure (mmHg) & $109.0 \pm 7.2$ & $139.2 \pm 25.6$ & $<0.001$ \\
\hline Diastolic Blood Pressure (mmHg) & $68.7 \pm 5.9$ & $83.8 \pm 12.5$ & $<0.001$ \\
\hline Blood Urea Nitrogen (mg/dl) & $14.1 \pm 3.7$ & $64.6 \pm 29.9$ & $<0.001$ \\
\hline Creatinine (mg/dl) & $0.9 \pm 0.2$ & $7.2 \pm 3.7$ & $<0.001$ \\
\hline eGFR (mL/min/1.73 m2) & $75.6 \pm 12.0$ & $12.5 \pm 15.5$ & $<0.001$ \\
\hline eGFR < $60(\mathrm{~mL} / \mathrm{min} / 1.73 \mathrm{~m} 2, \%)$ & $18(5.5)$ & $90(97.8)$ & $<0.0001$ \\
\hline Uric acid (mg/dl) & $4.6 \pm 1.3$ & $8.3 \pm 2.5$ & $<0.001$ \\
\hline Fasting blood sugar (mg/dl) & $85.8 \pm 6.6$ & $128.4 \pm 63.8$ & $<0.001$ \\
\hline Total protein (g/dl) & $7.4 \pm 0.4$ & $6.3 \pm 0.8$ & $<0.001$ \\
\hline Albumin $(\mathrm{g} / \mathrm{dl})$ & $4.4 \pm 0.2$ & $3.5 \pm 0.5$ & $<0.001$ \\
\hline AST (IU/I) & $21.6 \pm 5.2$ & $19.1 \pm 14.7$ & 0.115 \\
\hline ALT (IU/I) & $17.8 \pm 7.0$ & $19.2 \pm 22.4$ & 0.558 \\
\hline Total Cholesterol (mg/dl) & $186.1 \pm 25.6$ & $170.9 \pm 48.0$ & 0.004 \\
\hline
\end{tabular}

p, Categorical variable is summarized as count (\%) with statistical comparison using Chi-square

Continuous variables are summarized as mean \pm Standard Deviation with statistical comparison using T-test

$p$ value for different between non-obese and obese group 


\begin{tabular}{|llll|}
\hline & Control & CKD & p-value \\
\cline { 2 - 3 } & $(\mathbf{N}=330)$ & $(\mathbf{N}=92)$ & $<0.001$ \\
\hline Triglyceride $(\mathrm{mg} / \mathrm{dl})$ & $88.6 \pm 36.0$ & $127.11 \pm 77.8$ & $<0.001$ \\
\hline HDL Cholesterol $(\mathrm{mg} / \mathrm{dl})$ & $55.4 \pm 11.1$ & $44.7 \pm 16.4$ & 0.031 \\
\hline LDL Cholesterol $(\mathrm{mg} / \mathrm{dl})$ & $113.0 \pm 25.4$ & $102.0 \pm 38.1$ & \\
\hline$p$, Categorical variable is summarized as count $(\%)$ with statistical comparison using Chi-square \\
\hline Continuous variables are summarized as mean \pm Standard Deviation with statistical comparison using T-test \\
\hline$p$ value for different between non-obese and obese group & \\
\hline
\end{tabular}

Genotype and Allele Frequencies of IFNL3, IFNL2, IFNAR2, TLR9, IL-10RB, IL-22, IFNRA, IRF7, JAK2, and STAT3 Genes SNPs

The SNPs of IFNL3, rs148543092 (T > C) were significantly associated with CKD in the codominant and dominant model ( $\mathrm{T} / \mathrm{T}$ vs. $\mathrm{T} / \mathrm{C}$ and $\mathrm{T} / \mathrm{T}$ vs. $\mathrm{T} / \mathrm{C}+\mathrm{C} / \mathrm{C}, \mathrm{p}=0.013, \mathrm{OR}=2.50,95 \% \mathrm{Cl}=1.21-5.15)$. The SNPs of IFNL2, rs8103362 $(A>G)$ were significantly associated with CKD in the codominant, dominant and log-additive model (A/A vs. $A / G, p=0.013, O R=2.50,95 \% C l=1.21-5.15 ; A / A$ vs. $A / G+G / G, p=0.018, O R=2.37,95 \% C l=1.16-4.86$; $A / A$ vs. $A / G$ vs. $G / G, p=0.036, O R=2.14,95 \% \mathrm{Cl}=1.07-4.28$, respectively). The SNP of IFNRA2, rs $1051393(\mathrm{G}>\mathrm{T})$ was significantly associated with CKD in the codominant and log-additive model (G/G vs. T/T, $p=0.029, O R=$ $2.10,95 \% \mathrm{Cl}=1.08-4.09 ; \mathrm{G} / \mathrm{G}$ vs. $\mathrm{G} / \mathrm{T}$ vs. $\mathrm{T} / \mathrm{T}, \mathrm{p}=0.026, \mathrm{OR}=1.45,95 \% \mathrm{Cl}=1.04-2.02$, respectively). The SNP of $T L R 9, \mathrm{rs} 187084(\mathrm{~T}>\mathrm{C})$ was significantly associated with $\mathrm{CKD}$ in the codominant model $(\mathrm{T} / \mathrm{T}$ vs. $\mathrm{C} / \mathrm{C}, \mathrm{p}=0.016$, $\mathrm{OR}=2.26,95 \% \mathrm{Cl}=1.16-4.40)$, dominant model $(\mathrm{T} / \mathrm{T}$ vs. $\mathrm{T} / \mathrm{C}+\mathrm{C} / \mathrm{C}, \mathrm{p}=0.047, \mathrm{OR}=1.77,95 \% \mathrm{Cl}=1.01-3.10)$ and log-additive model ( $\mathrm{T} / \mathrm{T}$ vs. $\mathrm{T} / \mathrm{C}$ vs. $\mathrm{C} / \mathrm{C}, \mathrm{p}=0.015, \mathrm{OR}=1.50,95 \% \mathrm{Cl}=1.08-2.09$ ). The SNP of IL-22, rs2227484 $(G>A)$ was significantly associated with $C K D$ in the codominant model $(G / G$ vs. $G / A, p=0.040,0 R=1.95,95 \% \mathrm{Cl}$ $=1.03-3.69)$, dominant model ( $G / G$ vs. $G / A+A / A, p=0.046, O R=1.91,95 \% C l=1.01-3.62)$ (Table 3). There was no significant difference of genotype and allele frequencies between control and CKD in the IL-10RB gene polymorphisms (rs8178562 G > A, rs 2834167 A > G) and IRF7 gene polymorphism (Affix-52325648 T/del). There were no polymorphisms but only major allele homozygotes in the IFNRA (Affix-52347487), JAK2 (rs77375493), and STAT3 (rs113994139) (data not shown). 
Table 3

Distribution of frequencies of Interferon Lambda-Related Genotype in controls and CKD patients in model of inheritance

\begin{tabular}{|c|c|c|c|c|c|c|c|c|c|}
\hline \multirow[t]{3}{*}{ Gene } & \multirow[t]{3}{*}{ SNP number } & \multicolumn{8}{|c|}{ Model of Inheritance } \\
\hline & & \multicolumn{2}{|c|}{$\begin{array}{l}\text { Co-dominamt } \\
\text { genetic model }\end{array}$} & \multicolumn{2}{|c|}{$\begin{array}{l}\text { Dominamt genetic } \\
\text { model }\end{array}$} & \multicolumn{2}{|c|}{$\begin{array}{l}\text { Recessivet } \\
\text { genetic model }\end{array}$} & \multicolumn{2}{|c|}{$\begin{array}{l}\text { Log-Additivet } \\
\text { genetic model }\end{array}$} \\
\hline & & $\begin{array}{l}\text { OR }(95 \% \\
\mathrm{Cl})\end{array}$ & $\begin{array}{l}\mathrm{p}- \\
\text { value }\end{array}$ & $\begin{array}{l}\text { OR }(95 \% \\
\mathrm{Cl})\end{array}$ & $\begin{array}{l}\mathrm{p}- \\
\text { value }\end{array}$ & $\begin{array}{l}\text { OR } \\
(95 \% \\
\mathrm{Cl})\end{array}$ & $\begin{array}{l}\mathrm{p}- \\
\text { value }\end{array}$ & $\begin{array}{l}\text { OR } \\
(95 \% \\
\mathrm{Cl})\end{array}$ & $\begin{array}{l}p- \\
\text { value }\end{array}$ \\
\hline \multirow[t]{2}{*}{ IFNL3 } & rs148543092 & $\begin{array}{l}2.50 \\
(1.21- \\
5.15)\end{array}$ & 0.013 & $\begin{array}{l}2.50 \\
(1.21- \\
5.15)\end{array}$ & 0.013 & & & & \\
\hline & Thr108Ala & - & & & & & & & \\
\hline \multirow[t]{2}{*}{ IFNL2 } & rs8103362 & $\begin{array}{l}2.50 \\
(1.21- \\
5.15)\end{array}$ & 0.013 & $\begin{array}{l}2.37 \\
(1.16- \\
4.86)\end{array}$ & 0.018 & & & $\begin{array}{l}2.14 \\
(1.07- \\
4.28)\end{array}$ & 0.036 \\
\hline & Thr112Ala & - & & & & & & & \\
\hline \multirow[t]{2}{*}{ IFNAR2 } & rs1051393 & $\begin{array}{l}1.52 \\
(0.86- \\
2.69)\end{array}$ & 0.147 & $\begin{array}{l}1.68(0.98- \\
2.87)\end{array}$ & 0.057 & $\begin{array}{l}1.61 \\
(0.93- \\
2.79)\end{array}$ & 0.094 & $\begin{array}{l}1.45 \\
(1.04- \\
2.02)\end{array}$ & 0.026 \\
\hline & Phe10lle & $\begin{array}{l}2.10 \\
(1.08- \\
4.09)\end{array}$ & 0.029 & & & & & & \\
\hline \multirow[t]{2}{*}{ TLR9 } & rs187084 & $\begin{array}{l}1.56 \\
(0.86- \\
2.83)\end{array}$ & 0.147 & $\begin{array}{l}1.77 \\
(1.01- \\
3.10)\end{array}$ & 0.047 & $\begin{array}{l}1.69 \\
(1.00- \\
2.86)\end{array}$ & 0.052 & $\begin{array}{l}1.50 \\
(1.08- \\
2.09)\end{array}$ & 0.015 \\
\hline & T-1486C & $\begin{array}{l}2.26 \\
(1.16- \\
4.40)\end{array}$ & 0.016 & & & & & & \\
\hline \multirow[t]{4}{*}{$\mathrm{IL}-22$} & rs2227513 & $\begin{array}{l}3.72 \\
(0.96- \\
14.47)\end{array}$ & 0.058 & $\begin{array}{l}3.72 \\
(0.96- \\
14.47)\end{array}$ & 0.058 & & & & \\
\hline & $\mathrm{T}-111 \mathrm{C}$ & - & & & & & & & \\
\hline & rs2227484 & $\begin{array}{l}1.95 \\
(1.03- \\
3.69)\end{array}$ & 0.04 & $\begin{array}{l}1.91 \\
(1.01- \\
3.62)\end{array}$ & 0.046 & & & $\begin{array}{l}1.82 \\
(0.98- \\
3.39)\end{array}$ & 0.065 \\
\hline & G-701A & - & & & & & & & \\
\hline \multicolumn{10}{|c|}{$p$, Chi-square test $p$ value; $\mathrm{OR}$, odds ratio; $\mathrm{Cl}$, confidence interval } \\
\hline$p$ valı & ifferent betv & control & CKD & & & & & & \\
\hline
\end{tabular}

Replication of IFNL3, IFNL2, TLR9, and IL-22 Genes SNPs

The comparison of genotypic frequencies between cases and controls for all the SNPs analysed achieved a nominal significant value in four polymorphisms located in four different genetic regions. Although none of them 
withstand Bonferroni correction, we tried to replicate associations involving IFNL3, IFNL2, TLR9 and IL22 using a second sample set (Table 4).

Table 4

Distribution of frequencies of $T L R 9$ Genotype in replication

\begin{tabular}{|c|c|c|c|c|c|c|}
\hline TLR9 & Original sc & & Original set** & & Replication set & \\
\hline rs187084 & CKD & Controls & CKD with CGN & Controls & CKD with CGN & Controls \\
\hline Genotype & $(\mathrm{N}=92)$ & $(\mathrm{N}=330)$ & $(\mathrm{N}=58)$ & $(N=330)$ & $(\mathrm{N}=137)$ & $(\mathrm{N}=446)$ \\
\hline TT & 19 (20.6) & 102 (30.9) & 10 (17.2) & $102(30.9)$ & $29(21.2)$ & $141(31.6)$ \\
\hline TC & $45(48.9)$ & $157(47.6)$ & $31(53.4)$ & $157(47.6)$ & $72(52.5)$ & $210(47.1)$ \\
\hline $\mathrm{CC}$ & $28(30.4)$ & $71(21.5)$ & $17(29.3)$ & $71(21.5)$ & $36(26.3)$ & 95 (21.3) \\
\hline $\begin{array}{l}\text { TC + CC ge } \\
*: p=0.047 \\
\#: p=0.017\end{array}$ & $\begin{array}{l}\text { otype } \\
\text { OR = } 1.779 \\
O R=1.719\end{array}$ & $\begin{array}{l}\% \mathrm{Cl} 1.01-3 \\
\% \mathrm{Cl} 1.08-2\end{array}$ & $0 ; * \star: p=0.0180$ & $=2.2795 \%$ & 0-4.70; & \\
\hline \multicolumn{7}{|c|}{$p$, Categorical variable is summarized as count (\%) with statistical comparison using Chi-square } \\
\hline
\end{tabular}

No significant associations involving IFNL3, IFNL2 and IL22 were observed in the replication set. Regarding the rs 187084, in the TLR9 gene, a significant association was observed pooling the original and the replication sets ( $p$ $=0.017 \mathrm{OR}=1.7195 \% \mathrm{Cl} 1.08-2.71)($ Table 4$)$.

\section{Association of TLR9 SNP with clinical characteristics}

After adjustment for age, gender, BMI, hypertension, diabetes mellitus, and dyslipidemia as covariates whether examined the genotype distribution of $T L R 9$ gene polymorphism rs 187084 is associated with clinical characteristics (creatinine, eGFR, uric acid, total protein, and albumin) in both original and replication set of CKD group.

In both original and replication set, total protein level was significantly higher in homozygous $\mathrm{C} / \mathrm{C}$ genotype than $T / T+T / C$ genotype of $T L R 9$ gene, rs 187048 ( $6.57 \pm 0.65$ vs. $6.16 \pm 0.81, p=0.025: 6.29 \pm 0.78$ vs. $6.03 \pm 0.77, p=$ 0.049 , respectively). In original set, albumin level were significantly higher in homozygous $\mathrm{C} / \mathrm{C}$ genotype than $\mathrm{T} / \mathrm{T}$ $+T / C$ genotype $(3.72 \pm 0.45$ vs. $3.42 \pm 0.48, p=0.009)$. In replication set, eGFR level was significantly lower in homozygous $\mathrm{C} / \mathrm{C}$ genotype than $\mathrm{T} / \mathrm{T}+\mathrm{T} / \mathrm{C}$ genotype $(7.45 \pm 5.13$ vs. $10.28 \pm 8.89, \mathrm{p}=0.007$ ) (Table 5$)$. 
Table 5

Association of TLR9SNP with clinical characteristics in replication

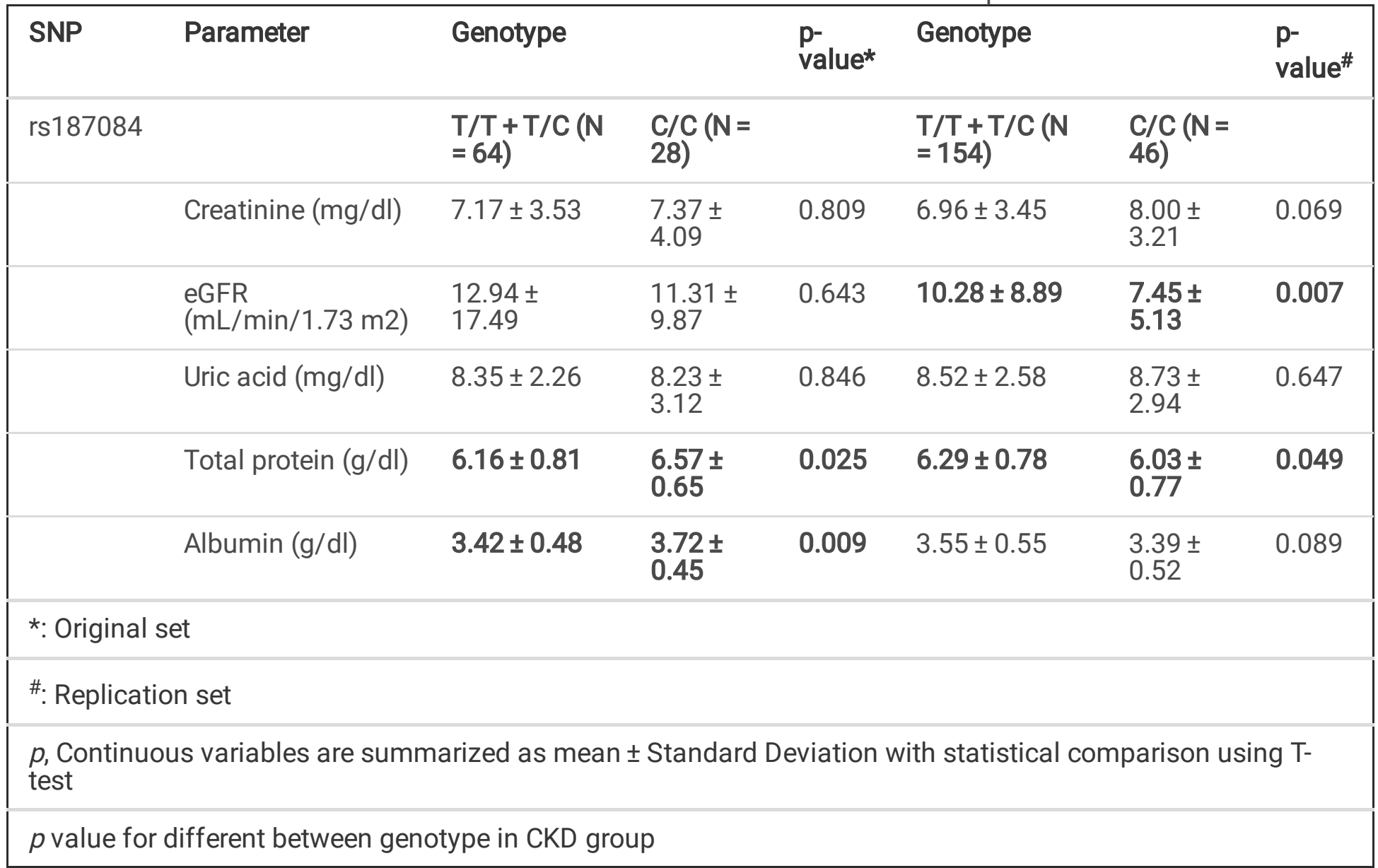

\section{Discussion}

This study examined the association between the polymorphisms of IIFNL3 (rs148543092 T > C; rs150748693 G > A), IFNL2 (rs8103362 A > G; rs59746524 T > C), IFNAR2 (rs2229207 T > C; rs1051393 G > T), TLR9 (rs5743836 T > C; rs187084 T > C), IL-22 (rs2227513 T > C; rs2227484 G > A; rs2227485 G > A) and IL-10RB (rs8178562 G > A; rs2834167 G > A) with the development among CKD patients as well as their clinical characteristics. Interferon Lambda have emerged as a new immune control cytokines with a special function controlling damage to maintain an immune balance and limit immunology. Also IFN $\lambda$ s indicates limiting inflammation to prevent damage to the host of chronic illnesses including asthma, auto-immune disease and colitis [20]. Genetic association of IFNL gene polymorphisms among humans expands to various illnesses, for instance, allergy, nonalcoholic fatty liver disease and several other viral diseases including that caused by the human immunodeficiency virus as well as HCV infection only [29]. The difference of expression levels by genotype of IFNL3 were shown in numerous researches, especially, recent research outcomes also verified this result in ex/in vivo conditions. These results demonstrate that difference of IFNL3 expression levels by the alleles at the three functional SNPs (rs28416813, rs4803217, and rs59702201) may have a function in the disease [30-32]. SwiatekKoscielna et al. [33] demonstrated that the marker of virological response and relapse was the SNP of IFNL3 in chronic hepatitis $C$ patients with hepatitis $C$ virus genotype 1 . The results of this research did not perform the polymorphism (rs28416813, rs4803217, and rs59702201) of IFNL3. The result of this research suggests the possibility of the association between the IFNL3 and IFNL2 polymorphisms (rs148543092 T > C; rs8103362 A > G, 
respectively) with CKD. This study also shows that the $\mathrm{C}$ allele of IFNL3 and G allele of IFNL2 was higher in the CKD group when compared with control group.

Several research reported on SNPs of INFAR2 in hepatitis B virus infection, specifically, there is a possibility that IFNAR2 polymorphisms is involved in chronic HBV infection susceptibility among Thailand population [34] and involved when determining IFN response and predictive marker of hepatitis B virus infection among Chinese Han population [35]. Ma et al. [36] reported that the polymorphism of IFNAR2 (rs1051393 G > T) is missense changing from phenylalanine to valine. This SNP might be important in the risk of HBV infection by influencing the expression of IFNAR2 protein on the surface of the cell resulting in anti-viral response and damaged signal transduction. This result suggests that the IFNAR2 polymorphisms (rs1051393 G > T) might have association with CKD. This research found that the T allele of IFNAR2 (rs1051393 G > T) was higher in the CKD group compared with control group. The interrelationship of this SNP seems to be a codominant effect by inheritance analysis model (major allele homozygotes vs. minor allele homozygotes). The result of this study indicates that the mechanism underlying the association between IFNAR2 SNP (rs1051393 G > T) and CKD is to control IFNAR2 expression, which in turn affects type I Interferon effect.

TLRs are evolved to recognize components of foreign pathogen and damage-associated molecular patterns [37]. TLR9 were associated with kidney disease including crescentic glomerulonephritis, IgA nephropathy and lupus nephritis [25, 38, 39]. Romani et al. [40] reported TLR9 promoter (rs187084 T-1486C) genetic variant might affect the susceptibility to antipsoriatic therapy response in patients with psoriasis and alter its functionality. Metaanalysis results showed that TLR9 rs187084 polymorphism may increase systemic erythematosus risk among Asians [41]. Other studies have shown the results that TLR9 SNPs (rs352139 and rs352140) may lead to the initiation and progression of chronic membranous glomerulonephritis and cervical cancer with human papilloma virus infection $[42,43]$. The results of this research show that the association between TLR9 gene polymorphisms (rs187084 T-1486C) with the development of CKD.

Both CKD and end-stage kidney disease are featured by increased levels of pro-inflammatory cytokine and inflammatory labeling. Cytokines may control the risk of developing kidney disease [44]. Cytokines induce resident cells to proliferate, metalloproteinase, bioactive lipids, expression of adhesion receptors, reactive oxygen/nitrogen species, procoagulant activity of endothelium and aberrant matrix metabolism. These molecules may be the action mediators of renin-angiotensin system and hemodynamic factors [45-52]. IL-10, a cytokine that is anti to inflammation and has numerous functions, is primarily secreted by monocyte and lymphocyte. Also, IL-10 interacts with interleukin 10 receptor. The receptor complex of IL-10 consists of IL-10 receptor 1 (IL-10R1) and IL10RB (IL-10 receptor2). First, IL-10 joins to IL-10R1, and induces structural alterations that enables IL-10RB to communicate with IL-10/IL-10R1 compounds. IL-10RB is also included in one of the constituents of IL-22R, IL-26R and interferon- $\lambda$ receptor [53]. Genetic variants of cytokine can affect transcription of gene and cytokine secretion and modulate the risk of progression of cardiovascular and kidney diseases [44]. Numerous studies have shown the interrelationship between $I L-10 R B$ polymorphism and several diseases. In fact, IL-10RB (rs2834167) polymorphism can contribute to the high blood pressure at the risk of ischemic stroke [54] and may offer protection against chronic HBV infections [55]. The results of this research did not show that the association between IL-10RB gene polymorphisms (rs2834167 and rs8178562) with the development of CKD.

IL-22, an IL-10-related cytokine, activates the upward adjustment of the acute-phase reactor. It also guides activation of JAK/STAT in several cell line including hepatomas, intestinal epithelial cells and mesangial cells [56]. Meta-analysis outcome has shown that IL-22 gene rs1179251 polymorphism may be a cancer risk factor but not 
rs2227485 polymorphism [57]. The rs2227485 SNP of IL-22 might have connection with the risk and multifocality of primary thyroid cancer according to Eun et al. [58]. The results of this research did not show that the association between polymorphisms (rs2227513 T > C; rs2227485 G > A) of IL-22 gene and the development of CKD, however, showed an association with rs2227484 polymorphism.

Although there are few limitations of this study, which are the small sample size used for comparison within CKD group, and not including various etiology of CKD such as hypertension and DM, this study have performed genetic analysis of association between IFNL induction and signal pathway genes such as IFNL3, IFNL2, IFNAR2, TLR9, $I L-22$, and $I L-10 R B$ and CKD for the first time.

We analyzed replicate associations involving IFNL3, IFNL2, TLR9 and IL22 using a second sample set. No significant associations involving IFNL3, IFNL2 and IL22 were observed in the replication set whereas concerning the rs187084, in the $T L R 9$ gene, a significant association was observed pooling the original and the replication sets.

In conclusion, the outcome of this study indicates the possibility of association between polymorphisms of IFNL induction and signal pathway genes with the CKD. Secondly, Our results seem to TRL 9 gene variant may be play a risk factor on CKD with CGN. Further research is needed in large-scale prospective CKD cohort study.

\section{Declarations}

\section{Acknowledgements}

The present research has been conducted by the Research Grant of Kidney Institute, Keimyung University in 2017.

\section{Compliance with ethical standards}

Conflict of interest The authors declare that they have no competing interest.

\section{References}

1. Levin A, Tonelli M, Bonventre J, et al. Global kidney health 2017 and beyond: a roadmap for closing gaps in care, research, and policy. Lancet. 2017;390:1888-917.

2. Hill NR, Fatoba ST, Oke JL, et al. Global Prevalence of Chronic Kidney Disease - A Systematic Review and Meta-Analysis. PLoS One. 2016;11:e0158765.

3. Fried LF, Katz R, Sarnak MJ, et al. Kidney function as a predictor of noncardiovascular mortality. J Am Soc Nephrol. 2005;16:3728-35.

4. Gansevoort RT, Correa-Rotter R, Hemmelgarn BR, et al. Chronic kidney disease and cardiovascular risk: epidemiology, mechanisms, and prevention. Lancet. 2013;382:339-52.

5. Zhang QL, Rothenbacher D. Prevalence of chronic kidney disease in population-based studies: systematic review. BMC Public Health. 2008;8:117.

6. Young BA, Katz R, Boulware LE, et al. Risk Factors for Rapid Kidney Function Decline Among African Americans: The Jackson Heart Study (JHS). Am J Kidney Dis. 2016;68:229-39.

7. O'Seaghdha CM, Fox CS. Genetics of chronic kidney disease. Nephron Clin Pract. 2011;118:c55-63. 
8. Köttgen A, Glazer NL, Dehghan A, et al. Multiple loci associated with indices of renal function and chronic kidney disease. Nat Genet. 2009;41:712-7.

9. Lu KC, Yang HY, Lin YF, et al. The T-1237C polymorphism of the Toll-like receptor-9 gene is associated with chronic kidney disease in a Han Chinese population. Tohoku J Exp Med. 2011;225:109-16.

10. Buraczynska M, Zukowski P, Ksiazek P, Kuczmaszewska A, Janicka J, Zaluska W. (2014) Transcription factor 7-like 2 (TCF7L2) gene polymorphism and clinical phenotype in end-stage renal disease patients. Mol Biol Rep 2014;41:4063-8.

11. Chambers JC, Zhang W, Lord GM, et al. Genetic loci influencing kidney function and chronic kidney disease. Nat Genet. 2010;42:373-5.

12. Okada Y, Sim X, Go MJ, et al. Meta-analysis identifies multiple loci associated with kidney function-related traits in east Asian populations. Nat Genet. 2020;44:904-9.

13. Gorski M, Tin A, Garnaas M, et al. Genome-wide association study of kidney function decline in individuals of European descent. Kidney Int. 2015;87:1017-29.

14. Kelly TN, Raj D, Rahman M, et al. The role of renin-angiotensin-aldosterone system genes in the progression of chronic kidney disease: findings from the Chronic Renal Insufficiency Cohort (CRIC) study. Nephrol Dial Transplant. 2015;30:1711-8.

15. Lazear HM, Nice TJ, Diamond MS. Interferon- $\lambda$ : Immune Functions at Barrier Surfaces and Beyond. Immunity 2015;43:15-28.

16. Sabat R. IL-10 family of cytokines. Cytokine Growth Factor Rev. 2010;21:315-24.

17. Hermant $P$, Michiels T. Interferon- $\lambda$ in the context of viral infections: production, response and therapeutic implications. J Innate Immun. 2014;6:563-74.

18. Donnelly RP, Dickensheets H, O'Brien TR. Interferon-lambda and therapy for chronic hepatitis C virus infection. Trends Immunol. 2011;32:443-50.

19. Lampertico $P$, Viganò $M$, Cheroni $C$, et al. IL28B polymorphisms predict interferon-related hepatitis B surface antigen seroclearance in genotype $D$ hepatitis $B$ e antigen-negative patients with chronic hepatitis $B$. Hepatology. 2013;57:890-6.

20. Andreakos E, Zanoni I, Galani IE. Lambda interferons come to light: dual function cytokines mediating antiviral immunity and damage control. Curr Opin Immunol. 2018;56:67-75.

21. Swiecki M, Colonna M. Type I interferons: diversity of sources, production pathways and effects on immune responses. Curr Opin Virol. 2011;1:463-75.

22. Hillyer P, Mane VP, Schramm LM, et al. Expression profiles of human interferon-alpha and interferon-lambda subtypes are ligand- and cell-dependent. Immunol Cell Biol. 2012;90:774-83.

23. Thomson SJ, Goh FG, Banks H, et al. The role of transposable elements in the regulation of IFN-lambda1 gene expression. Proc Natl Acad Sci U S A. 2009;106:11564-9.

24. Miknis ZJ, Magracheva E, Li W, et al. Crystal structure of human interferon- $\lambda 1$ in complex with its high-affinity receptor interferon- $\lambda$ R1. J Mol Biol. 2010;404:650-64.

25. Summers SA, Steinmetz OM, Ooi JD, et al. Toll-like receptor 9 enhances nephritogenic immunity and glomerular leukocyte recruitment, exacerbating experimental crescentic glomerulonephritis. Am J Pathol. 2010;177:2234-44. 
26. Gluba A, Banach M, Hannam S, et al. The role of Toll-like receptors in renal diseases. Nat Rev Nephrol. 2010;6:224-35.

27. Syedbasha M, Egli A. (2017) Interferon Lambda: Modulating Immunity in Infectious Diseases. Front Immunol 2017;8:119.

28. Stevens LA, Stoycheff N. Standardization of serum creatinine and estimated GFR in the Kidney Early Evaluation Program (KEEP). Am J Kidney Dis. 2008;51(4 Suppl 2):77-82.

29. Chinnaswamy S. Gene-disease association with human IFNL locus polymorphisms extends beyond hepatitis C virus infections. Genes Immun. 2016;17:265-75.

30. Chinnaswamy S. Genetic variants at the IFNL3 locus and their association with hepatitis $\mathrm{C}$ virus infections reveal novel insights into host-virus interactions. J Interferon Cytokine Res. 2014;34:479-97.

31. Noureddin M, Rotman Y, Zhang F, et al. Hepatic expression levels of interferons and interferon-stimulated genes in patients with chronic hepatitis C: A phenotype-genotype correlation study. Genes Immun. 2015;16:321-9.

32. Kurbanov F, Kim Y, Latanich R, et al. IFNL3 genotype is associated with differential induction of IFNL3 in primary human hepatocytes. Antivir Ther. 2015;20:805-14.

33. Świątek-Kościelna B, Kałużna E, Strauss E, et al. Prevalence of IFNL3 rs4803217 single nucleotide polymorphism and clinical course of chronic hepatitis C. World J Gastroenterol. 2017;23:3815-24.

34. Romporn S, Hirankarn N, Tangkijvanich P, et al. Association of IFNAR2 and IL10RB genes in chronic hepatitis B virus infection. Tissue Antigens. 2013;82:21-5.

35. Gong QM, Kong XF, Yang ZT, et al. Association study of IFNAR2 and IL10RB genes with the susceptibility and interferon response in HBV infection. J Viral Hepat. 2009;16:674-80.

36. Ma N, Zhang X, Yang L, et al. Role of Functional IFNL4, IFNLR1, IFNA, IFNAR2 Polymorphisms in Hepatitis B virus-related liver disease in Han Chinese population. J Viral Hepat. 2018;25:306-13.

37. Delneste Y, Beauvillain C, Jeannin P, et al. Innate immunity: structure and function of TLRs. Med Sci (Paris). 2007;23:67-73.

38. Pawar RD, Ramanjaneyulu A, Kulkarni OP, et al. Inhibition of Toll-like receptor-7 (TLR-7) or TLR-7 plus TLR-9 attenuates glomerulonephritis and lung injury in experimental lupus. J Am Soc Nephrol. 2007;18:1721-31.

39. Papadimitraki ED, Tzardi M, Bertsias G, et al. Glomerular expression of toll-like receptor-9 in lupus nephritis but not in normal kidneys: implications for the amplification of the inflammatory response. Lupus. 2009;18:831-5.

40. Romaní J, Julià M, Lozano F, et al. Toll-like receptor 9 promoter polymorphism as a predictive factor of narrow-band UVB phototherapy response in patients with psoriasis. Photodermatol Photoimmunol Photomed. 2015;31:98-103.

41. Wang D, Zhang C, Zhou Z, et al. TLR9 polymorphisms and systemic lupus erythematosus risk: an update meta-analysis study. Rheumatol Int. 2016;36:585-95.

42. Chen YT, Wei CC, Ng KL, et al. Toll-like receptor 9 SNPs are susceptible to the development and progression of membranous glomerulonephritis: 27 years follow-up in Taiwan. Ren Fail. 2013;35:1370-5.

43. Lai ZZ, Ni-Zhang, Pan XL, et al. Toll-like receptor 9 (TLR9) gene polymorphisms associated with increased susceptibility of human papillomavirus-16 infection in patients with cervical cancer. J Int Med Res. 2013;41:1027-36. 
44. Rao M, Wong C, Kanetsky P, et al. Cytokine gene polymorphism and progression of renal and cardiovascular diseases. Kidney Int. 2007;72:549-56.

45. Nakamura T, Miller D, Ruoslahti E, et al. Production of extracellular matrix by glomerular epithelial cells is regulated by transforming growth factor-beta 1. Kidney Int. 1992;41:1213-21.

46. Coleman DL, Ruef C. Interleukin-6: an autocrine regulator of mesangial cell growth. Kidney Int. 1992;41:6046.

47. Horii Y, Muraguchi A, Iwano M, et al. Involvement of IL-6 in mesangial proliferative glomerulonephritis. J Immunol. 1989;143:3949-55.

48. Bevilacqua MP, Pober JS, Majeau GR, et al. Recombinant tumor necrosis factor induces procoagulant activity in cultured human vascular endothelium: characterization and comparison with the actions of interleukin 1. Proc Natl Acad Sci U S A. 1986;83:4533-7.

49. Sharma K, Cook A, Smith M, et al. TGF-beta impairs renal autoregulation via generation of ROS. Am J Physiol Renal Physiol. 2005;288:F1069-77.

50. Park S, Chang YH, Cho YJ, et al. Cytokine-regulated expression of vascular cell adhesion molecule-1 in human glomerular endothelial cells. Transplant Proc. 1998;30:2395-7.

51. Zager RA, Johnson A. Renal cortical cholesterol accumulation is an integral component of the systemic stress response. Kidney Int. 2001;60:2299-310.

52. Atkins RC. Interleukin-1 in crescentic glomerulonephritis. Kidney Int. 1995;48:576-86.

53. Donnelly RP, Sheikh F, Kotenko SV, et al. The expanded family of class II cytokines that share the IL-10 receptor-2 (IL-10R2) chain. J Leukoc Biol. 2004;76:314-21.

54. Park HK, Kim DH, Yun DH, et al. Association between IL10, IL10RA, and IL10RB SNPs and ischemic stroke with hypertension in Korean population. Mol Biol Rep. 2013;40:1785-90.

55. Romporn S, Hirankarn N, Tangkijvanich P, et al. Association of IFNAR2 and IL10RB genes in chronic hepatitis B virus infection. Tissue Antigen. 2013;82:21-5.

56. Lejeune D, Dumoutier L, Constantinescu S, et al. Interleukin-22 (IL-22) activates the JAK/STAT, ERK, JNK, and p38 MAP kinase pathways in a rat hepatoma cell line. Pathways that are shared with and distinct from IL-10. J Biol Che. 2002;277:33676-82.

57. Zhang J, Zhao T, Xu C, et al. Four polymorphisms in the IL-22 gene and the risk of cancer: A meta-analysis. J Evid Based Med. 2018;11:101-4.

58. Eun YG, Shin IH, Lee YC, et al. Interleukin 22 polymorphisms and papillary thyroid cancer. J Endocrinol Invest. 2013;36:584-7. 